\title{
PYGMALION AND THE OWL OF MINERVA: THE PHILOSOPHY OF REVOLUTION BY N.V. USTRYALOV
}

\author{
Anton A. Voytenko \\ Centre for Egyptological Studies of the Russian Academy of Sciences, Moscow, Russian Federation
}

\begin{abstract}
Introduction. The article examines the theoretical views on revolution as a socio-political phenomenon advanced by N.V. Ustryalov (1890-1937), main ideologist of National Bolshevism. Methods and materials. The article focuses mainly on the publicistic works by N.V. Ustryalov. The task of identifying general theoretical constructs dissolved in the general journalistic discourse or veiled for tactical reasons requires the correct interpretation of images and symbols, careful analysis of all the content, as well as the "reverse" formatting of it in a consistent concept. Analysis. Ustryalov differentiated revolution from other similar social phenomena (coup detat, riot, rebellion, etc.). In his point of view, revolution has several unique features: it follows sine and passes its peak in the middle, it "deepens" at its peak to a "clear idea", which is not implemented, and it is characterized by "heterogeneous goals". There is a good reason to assume that Ustryalov considered the stages of the French Revolution as an invariant for a revolution as such. In the article, the stages of the Russian Revolution in Ustryalovs assessing are analyzed: its general coincidences with the French revolution, the difference in their secondary factors and scenarios. Results. The author suggests that Ustryalov based on his analysis of the Russian Revolution and the general development of Russia in the $1900 \mathrm{~s}-1920 \mathrm{~s}$ of the $20^{\text {th }} \mathrm{c}$. was able to formulate a version of Russian history of modern times that is relevant and actual at the moment, because it explains consistent dialectical continuity from the Russian Empire to the USSR, and is the least traumatic for the historical memory of the majority of the population of Russia at the present stage.

Key words: Nikolay Ustryalov, National Bolshevism, Russian Revolution, history of intellectual pursuit in Russia in the $20^{\text {th }}$ century, Russian emigration.

Citation. Voytenko A.A. Pygmalion and the Owl of Minerva: The Philosophy of Revolution by N.V. Ustryalov. Vestnik Volgogradskogo gosudarstvennogo universiteta. Seriya 4. Istoriya. Regionovedenie. Mezhdunarodnye otnosheniya [Science Journal of Volgograd State University. History. Area Studies. International Relations], 2020, vol. 25, no. 3, pp. 214-224. (in Russian). DOI: https://doi.org/10.15688/jvolsu4.2020.3.19
\end{abstract}

УДК 947

ББК 63.3(2)

Дата поступления статьи: 10.11.2018 Дата принятия статьи: 15.05.2019

\section{ПИГМАЛИОН И СОВА МИНЕРВЫ: ФИЛОСОФИЯ РЕВОЛЮЦИИ Н.В. УСТРЯЛОВА}

\author{
Антон Анатольевич Войтенко \\ Центр египтологических исследований РАН, г. Москва, Российская Федерация
}

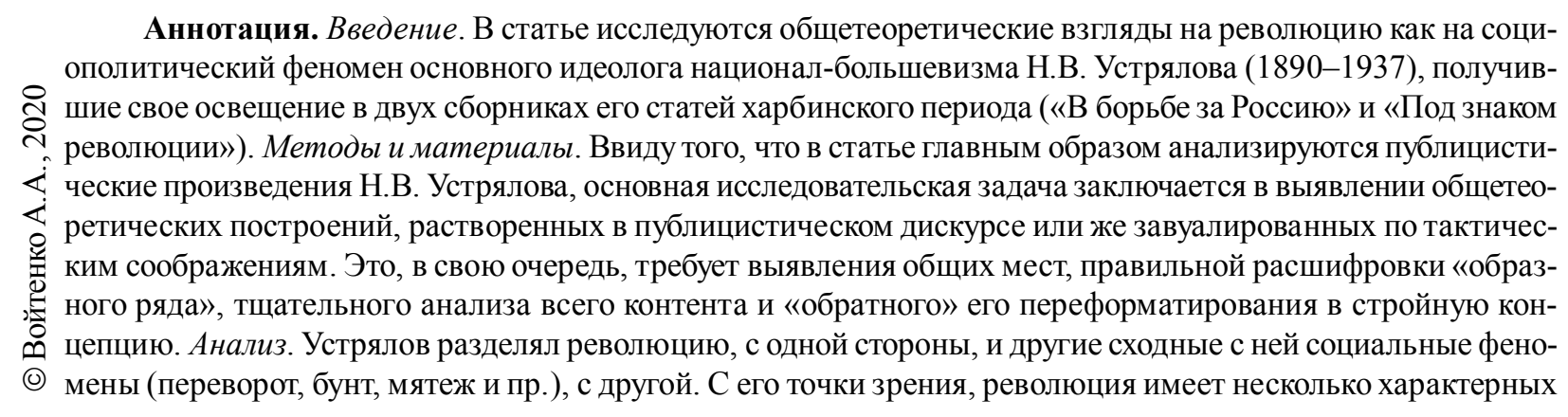


особенностей: она развивается по синусоиде (свой пик она проходит в середине), на своем пике «углубляется» до «чистой идеи», являющейся нереализуемой в принципе, и характеризуется «гетерогенией целей», когда провозглашенные задачи революции и методы их решения постепенно меняются местами. Есть веские основания предполагать, что Устрялов рассматривал этапы развития Великой французской буржуазной революции как инвариантные любой революции. Далее в статье анализируются оценка и характер протекания этих этапов в период русской революции в оценке Устрялова: общие закономерности с французской революцией и различия во второстепенных факторах и сценариях протекания основных этапов. Результаты. Автор статьи предполагает, что на основе анализа русской революции и общего развития России в 1900-1920-е гг. ХХ в. Устрялову удалось сформулировать такую версию истории России новейшего времени, которая является актуальной и востребованной в настоящее время, поскольку непротиворечиво объясняет диалектическую преемственность Российской империи и СССР и в наименьшей степени травмирует историческую память большинства населения России на современном этапе.

Ключевые слова: Н.В. Устрялов, национал-большевизм, русская революция, история интеллектуальной мысли России в XX веке, русская эмиграция.

Цитирование. Войтенко А. А. Пигмалион и сова Минервы: философия революции Н.В. Устрялова // Вестник Волгоградского государственного университета. Серия 4, История. Регионоведение. Международные отношения. - 2020. - Т. 25, № 3. - С. 214-224. - DOI: https://doi.org/10.15688/jvolsu4.2020.3.19

Введение. Удивительно осознавать, что основной идеолог национал-большевизма, «харбинский одиночка» Николай Васильевич Устрялов (1890-1937), идеи которого являются фундаментом идеологии левоконсервативного крыла современной общественной мысли России, сформировавшегося вокруг газеты «Завтра» и интернет-канала «День» (февраль и «феврализм» как время и идеология энтропии русской государственности, идея Вечной России, большевизм как новая точка сборки Большой России и др.), практически никак не учтен, не почтен и не представлен в пантеоне его героев и духовных наставников. Вопрос о роковой «забывчивости» в отношении Устрялова и его наследия уже поднимался, хотя предложенные ответы (см.: [11, с. 8]), как нам кажется, не совсем верны. Возможно, дело в том, что учитель новых левых патриотов является не человеком «слева», а человеком «справа», в котором не было ничего от марксизма и большевизма (cp. [11, с. 27]).

Научные публикации, так или иначе затрагивающие взгляды Н.В. Устрялова и идеологию национал-большевизма в целом, выходят начиная с 1970-х гг. (см.: [2, с. 2-6; 6, с. 16 ; 9, с. 10-17]). Относительно недавно по Устрялову были защищены как минимум три диссертации (см.: [2; 6; 9]), нет недостатка и в научных статьях (см., например, [3; 10; 14]). Однако, как нам представляется, в обширной историографии, посвященной наследию Устрялова, не достает системного анализа, способного выявить эвристический потенциал его идей. Самым удачным опытом системного подхода, определяющего центральное место взглядов Устрялова в контексте генезиса и общего развития национал-большевизма, можно считать монографию М. Агурского [1], явившуюся в свое время своеобразной «точкой отсчета» для последующих исследований, но остающейся, на наш взгляд, на пока еще не досягаемой высоте - даже если учесть ряд ее недостатков. Определенный интерес также представляет вступительная статья С.М. Сергеева к изданию работ Устрялова 2003 г. [11, с. 5-47], но это, скорее, публицистическое эссе. В статье предложены несколько свежих и интересных идей, оставшихся, впрочем, неразвитыми до конца.

Предметом нашей статьи будет реконструкция взглядов Н.В. Устрялова на революцию как на социополитический феномен в харбинский период его жизни, точнее, на том его этапе (1920-1927), когда он в своей публицистике формулирует основные положения национал-большевизма. Но, поскольку в публицистике Устрялова «философия революции» плотно встроена в его анализ истории России с 1900-х по конец 1920-х гг. и общеевропейского кризиса начала этого столетия, то мы сочли возможным не оставить без внимания и эти темы.

Методы. Большинство статей харбинского периода жизни Устрялова были изначально опубликованы в газете «Новости жизни». Сам жанр и формат газетной статьи отличается рядом особенностей и накладывает на 
автора ряд специфических ограничений. «Дискурс» такого рода высказывания помимо компактности, связанной с ограниченным объемом текста, несет в себе два плана: наряду с общетеоретическими идеями неизбежно присутствует «злоба дня» - тот конкретный повод, по которому статья была написана - a сама подача материала подразумевает определенную «пунктирность» и образность (или, по выражению самого Устрялова, «тезисы и намеки»). Есть и иная причина такой тезисности: в переписке он признается, что более откровенные и развернутые высказывания могут лишить его аудитории в России [13, с. 20]. Поэтому задача изучения общетеоретических построений, растворенных в потоке текущего момента или же завуалированных по тактическим соображениям, представляет для исследователя определенную сложность и требует, помимо выявления общих мест, правильной расшифровки «образного ряда» еще и тщательного анализа всего контента и «обратного» его переформатирования в стройную концепцию. Второй насущной задачей является адекватное выражение мысли Устрялова в категориях современной культурологии и политологии, что должно «выравнивать горизонт», то есть проверять степень актуальности его идей, выявлять их «скрытые смыслы» и потенциал, способный помочь выстроить непротиворечивую версию истории России XX в., не травмирующую (или травмирующую в наименьшей степени) историческую память большинства ее населения на нынешнем историческом этапе.

Материалы. Основным материалом для анализа будут тексты из двух его известных сборников «В борьбе за Россию» и «Под знаком революции» по двум вышедшим в последнее время изданиям $[11 ; 12]$. В качестве дополнительного материала привлекаются опубликованная переписка Н.В. Устрялова с П.П. Сувчинским [13] и фрагменты из его писем к разным лицам [11, с. 39-42]. Привлечение дополнительного материала необходимо для прояснения некоторых деталей концепции Устрялова, поскольку в переписке он излагает свои мысли более свободно, чем в своей публицистике. Часть писем относится к более позднему периоду, что позволяет увидеть завершение его идей, которые остались незавершенными на страницах его работ 1920-1927 годов.

Анализ. Не будет преувеличением сказать, что в основе мировоззрения Устрялова лежит этатизм («Только бы Россия была мощна, велика, страшна врагам. Остальное приложится» $[12$, с. 340$])$. Однако следует прояснить характер подобного этатизма в харбинский период его жизни. Наиболее полно его взгляды на государство выражены в статье «Судьба Европы» (1924 г.) и сконцентрированы в следующем абзаце: «Система власти уходит корнями в систему культуры. Социальная жизнь непосредственно обусловливается всем духовным складом общества, стилем его дум, чувств, стремлений <...> Государство всегда в известном смысле "надстройка". Оно не только “форма” определенных экономических отношений, меняющаяся вместе с ними, но и воплощение общекультурного миросозерцания данного исторического периода, данной социальной среды. Каждый тип культуры находит свое выражение в соотвествующем образе государственности, продолжается в нем, творит его» [12, с. 302]. Таким образом, понятно, что государство для Устрялова - это не онтологическая единица (ею является нация), а онтологическая матрица, слепок, точка пересечения культурных, социальных, политических и иных отношений, свойственных нации на данном историческом этапе. Государство для Устрялова - это примерно то же, чем для Маркса является понятие «товара» как объективированной точки пересечения человеческих отношений (культурных, социальных, производственных и т. д.), которые меняются в процессе исторического развития. С той только разницей, что в отличие от марксового «товара» «государство» Устрялова не обладает свойствами самостоятельного бытия. Но тем не менее эта матрица выполняет важную функцию каркаса или системного контура. Подобные взгляды не соотносятся с ранее высказанными Устряловым положениями о государстве (наиболее ясно в его ранней статье «К вопросу о русском империализме»), которые предполагают наличие у него сущностных признаков («государства - те же организмы, одаренные душой и телом, духовными и физическими качествами» (цит. по: [11, с. 25])), равно как и с 
высказанной там же идеей о том, что государство создает нацию (чего нам не удалось обнаружить на страницах его публицистики 1920-1927 гг., где явно прослеживается только мысль о том, что народ/нация создает и государство и культуру, то есть именно нация является актором и онтологической единицей). Возможных ответов два: либо представления Устрялова по этому вопросу менялись, либо он не был в нем до конца последователен.

Не менее важным для Устрялова является понятие нации. По счастью, в статье «О русской нации» (1927 г.) он достаточно полно высказывается по этому вопросу. Все внешние («объективные») признаки нации (расовая, политическая, языковая, религиозная, географическая) являются для него второстепенными. Устрялов, опираясь на Г. Еллинека, утверждает, что основной критерий здесь «субъективный», то есть то, что сейчас принято называть «идентичностью» («нация есть состояние сознания < .. > Общность традиций, потребностей, стремлений <...> Общность исторических судеб, общность воспоминаний, прочувствованное, а затем и осознанное единство воли к совместной жизни. Наследственная привычка, переходящая в общую природу и обособленный характер») [12, с. 310]). И главным стержнем, вокруг которого формируется «состояние сознания», является то, что сейчас принято называть «исторической памятью». Именно так следует, на наш взгляд, понимать слова Устрялова о «культурных символах» и «нетленных ценностях», которые он пытается раскрыть через цитату из Н.А. Бердяева (см.: [12, с. 310]). Но нация, как и государство, - это подвижное, исторически изменяемое понятие («не данность, а задание и становление» [12, с. 311]). Полное понимание национальной идентичности (или «внутреннего смысла ее единства») возможно лишь после исчезновения («исторического исчерпания») ее носителей [12, с. 311]. Самое главное для нашей темы - это уяснить важную для мировоззрения Устрялова подвижность и изменяемость как основной онтологической единицы (нации), так и ее матрицы (государства).

Теперь, чтобы вплотную приблизиться к основной теме статьи, перейдем к анализу Устряловым исторической ситуации в Европе и России в начале XX века. Кризис начала века, с его точки зрения, подводит итог процессам развития Европы после французской революции. Он называет его кризисом «политических форм западного конституционализма» [12, с. 224], кризисом «великих принципов 89 г.», кризисом «формальной демократии», осложненным «болезнью европейской культуры, ставящей под вопрос и под удар многие общепризнанные, казалось бы, ценности новейшей европейской истории» [12, с. 225]. Фактически Устрялов указывает на структурный кризис, выход из которого связан с радикальными изменениями всех систем: социальноэкономических, политико-правовых и культурных. Старые системы не имеют четкого «проекта будущего» и не способны его создать, заменяя реальное проектирование фабриками «симулякров» (по терминологии Устрялова «фальшфайеров»: «Хитроумными комбинациями, мастерскими маневрами старается Европа предотвратить окончательную катастрофу: все чудеса парламентской техники, покладистой печати, патетических ораторов, прирученного социализма - к ее услугам» [12, c. 298]). Французская революция провозгласила два принципа: «личные права» и «народный суверенитет». Однако они соотносятся между собой как сообщающиеся сосуды [12, с. 235-236]. Развитие обществ Европы шло по линии развития «личных прав», что привело к дисбалансу всей системы: повышение уровня свободы характеризовалось понижением общественного суверенитета, а проще говоря, углублением неравенства, сопровождавшимся в культурном плане созданием иллюзии положительной социальной мобильности (Устрялов приводит слова Лебона о том, что демократия также как и аристократия создает касты, с той только разницей, что «каждый может туда войти, или думать, что может войти» (курсив наш. - A. В.) [12, с. 236]). Решения проблемы в рамках прежних систем паллиативны и не действенны (государство как «организованная жалость»), поскольку эффективные изменения ситуации в иную сторону неизбежно приведут к обратному перетеканию в сосудах. Здесь Устрялов цитирует Еллинека: «Развитие культурных функций государства представляется процессом непрерывной экспроприации в отношении индивидуальной деятельности» (курсив наш. - 
A. B.) [12, с. 236]. Выход из кризиса, закономерным результатом которого была Первая мировая война, Устрялов усматривает в усилении роли государства во всех сферах и демонтаже прежних политико-правовых систем: «эпоха субъекта» сменяется «эпохой объективности», исчезает идея «субъективного права», ее заменяет принцип «общественной функции». Мир «демократий» заменяется миром «идеократий», одновременно берущих на вооружение и эгалитаристские принципы и этатизм: «В исторической атмосфере веет "тиранией альтруизма". Культура грядущего столетия реставрирует словно концепцию Левиафана - только с непременным “кольцом общего блага" в ноздрях» [12, с. 237]. Одним из возможных инструментов, способствующих осуществлению этого перехода, является революция: «История разрывает устаревшие формы механического демократизма, и там, где они не хотят спадать безболезненно <..> мы наблюдаем революции и государственные перевороты» [12, с. 240].

Кризис в России носит иной характер. Россия «не знала формально-демократического строя» $[12$, с. 244]. Своеобразие российской ситуации можно понять из следующих слов Устрялова: «Старая Россия уже не скажет нового слова "гнилой Европе", ибо сама сгнила раньше нее» [12, с. 301]. Суть кризиса - в старой социальной стратификации, неадекватности элит (правящего слоя, то есть служилого дворянства, и культурного слоя, то есть интеллигенции), а также старых государственных форм (дворянская монархия), которые перестали эффективно отвечать на исторические «вызовы»: «Старая Россия, упершаяся чугунным александровым конем в тупик, не знающая выхода из тупого оцепенения, съедаемая глубоким внутренним недугом» $[12$, c. 105]. Более полно своей мысли Устрялов не раскрывает, указывая лишь на экономическую и техническую отсталость России накануне войны и недовольство всех всеми [12, c. 326]. Назревшая необходимость обновления государственных форм, обусловленная историческим развитием нации, и неэффективный ответ на внешний «вызов» (мировую войну) соединились в начале XX в. в такой конфигурации, что революция являлась едва ли не единственным способом для социально-по- литической трансформации России: «Та бездна исторического зла, которая склонилась перед революцией чуть ли не во всех областях русской жизни, могла быть уничтожена, очевидно, только катастрофою. На эволюцию в нашем государственном организме не хватило сил и здоровья» [12, с. 161].

Свои общетеоретические взгляды на революцию Устрялов высказывает в статье «Потерянная и возвращенная Россия» (1922 г.). Прежде всего он отделяет ее от переворотов (каковыми, по его мнению, были французская революция 1830 г. и английская 1688 г.), мятежей и смут. Революция является гораздо более масштабным историческим феноменом, имеющим свои собственные законы развития. Основная особенность революций состоит в том, что они «всегда органически и подлинно национальны, какими бы идеями они ни воодушевлялись, какими бы элементами ни пользовались для своего торжества» [12, c. 137]. Таким образом, Устрялов считает, что революция является инструментом выполнения национальных задач, какой бы при этом ни была ее внешняя «оболочка» (цели, программа, лозунги). Революции «всенародны, то есть захватывают собою всю страну, жизненно отражаются на всех, даже самых далеких от “политики" слоях населения» [12, c. 137]. Если держать в голове всю совокупность устряловской публицистики «харбинского периода», то можно сказать, что этот признак помимо чисто статистической масштабности, которая качественно отличает революцию от мятежа или переворота, означает еще и существенное социальное «переформатирование» общества: замену элит, полное или частичное выпадение одних социальных слоев, изменение имущественно-правового статуса и экономического положения других. Революции «экстремичны и непременно “углубляются" до “чистой идеи", не имеющей корней в наличной действительности, но опережающей ее и становящейся затем активной силой целой эпохи» [12, с. 137]. Итак, характерным признаком революции является несоответствие выполняемых ею реальных национальных целей и заявленных задач. Этот дисбаланс яснее всего проявляется в пиковой фазе революции, но именно «идеальные» задачи обеспечивают ее влияние на внешнем 
контуре. Революции «в силу своей экстремичности $<\ldots$..> разрушительны в тот период своего развития, который интересы данной среды приносит в жертву “чистой идее”» [12, с. 137].

Для характеристики революции Устрялов обычно использует два образа, казалось бы, не совместимые с процессом, имеющим четкую последовательность: «стихия» и «наводнение». Но на самом деле противоречия нет: и тот и другой образ просто указывают на отмену законов обычного развития в революционный период и разрушительную динамику его основного (пикового) этапа. «Стихия» подразумевает многовекторность, отсутствие прямой зависимости между программой (целями, задачами, лозунгами) и результатами, широкий спектр участвующих в революции социальных групп. «Наводнение» отражает основную конфигурацию ее протекания (о чем речь ниже), которая предполагает, что свой пик она проходит в середине пути.

Уже высказывалась мысль о том, что основой устряловского анализа русской революции был метод аналогий с французской революцией $[11$, с. 29]. Но в этом нет заслуги Устрялова: в то время их проводили многие, можно вспомнить, например, Н.П. Милюкова или Л.Д. Троцкого. Но, как нам представляется, значение построений Н.В. Устрялова состоит в том, что он применил этот метод последовательнее других. Есть основания предполагать, что основные этапы французской революции Устрялов считал инвариантными для любой революции. Они же проявлялись и в русской революции, поэтому можно было спрогнозировать ее финал (тогда, когда он еще не был ясен). Устрялов понимал также, что при их конкретном воплощении в русской революции будет ряд различий с французской: в длительности, сценариях, конфигурации групп и т. д. Но логика развития остается одной и той же: революция развивается не по экспоненте, а по синусоиде, и свой пик она проходит в середине пути (отсюда, как мы уже писали, и образ «наводнения»).

Как известно, французская революция имела четыре основных этапа, которые можно обозначить как «жиронда», «якобинская диктатура», «термидор» и «брюмер». При описании февраля 1917 г. Устрялов не использует понятия «жиронда», но по некоторым кос- венным данным можно предполагать, что именно такие аналогии он и проводит. В записной книжке (1920 г.) он пишет, что «якобинцы нашей революции» своей политической одаренностью и изворотливостью затмили свой оригинал, тогда как французские жирондисты «несравненно ярче наших» [12, с. 337]. Аналогии «большевики»-«якобинцы» и «февралисты»-〈жирондисты» в данном случае не вызывают особого сомнения. Другой пример статья о Пестеле (1925 г.), где Пестель - «якобинец» и «большевик», а Муравьев и другие федералисты - деятели «русского жирондизма» $[12$, с. $272,274,276]$. Этап русской «жиронды» он характеризует как окончательный демонтаж дворянской монархии (первый и самый сильный удар по которой нанесла мировая война), а заодно и государства как такового: «Государство русское растворилось в народной стихии, умерло» [12, с. 184].

Суть «февраля» заключалась в том, что к власти пришла интеллигенция, постоянно стоявшая в оппозиции к власти, но в силу своей социальной природы и ментальности не способная эффективно осуществлять управленческие функции: «Начальство ушло, и у государственного руля в трагичнейшую минуту нашей национальной истории внезапно очутилась сама русская интеллигенция - со всеми ее навыками, со всеми ее идеями, со всем ее прошлым» [12, с. 207]. В результате - быстрая и полная энтропия во всех сфеpax: «В месяцы “февраля” основным чувством ощущается именно стыд. Никакого величия, ни грана подлинной трагедии, ни йоты действительного героизма. Разгул мелкого беса, дешевых чувств, кургузых мыслей, дряблых сердец» [12, с. 185]. Но на этапе «жиронды» революция развивается по нарастающей, и Устрялов как истинный диалектик (в гегелевском смысле этого слова) усматривает положительный момент «февраля» в том, что в хаосе его безвластья на арену смогли выдвинуться те силы, исторической задачей которых было проведение новой сборки России и придания ей новой государственной формы: «И растворившаяся в пространствах Россия вновь восстает из пространств. В новом облике, в новом одеянии. И плохи те патриоты, которые не узнают ее в нем $<\ldots>$ Значит, они чтили только фасад еe, а не субстанцию» [12, с. 187]. 
С приходом большевиков к власти в октябре 1917 г. начинается этап «якобинской диктатуры». Развитие революции достигает пика и, по мысли Устрялова, именно тогда она становится великой. Именно на этом этапе происходит «углубление» революции до «чистой идеи» и формируется та «оболочка», под которой позже будут, с одной стороны, решаться национальные задачи, с другой стороны, расти влияние страны на внешнем контуре. На этом этапе происходит «момент истины» для русской интеллигенции. К власти приходит наиболее радикальная ее часть, способная идти до конца, обладающая в отличие от «февралистов» и вождей белого движения «эросом власти» (ср. [12, с. 337]), но в то же время реализующая ее сценарии: «Большевизм не только сумел вовремя учесть стремление масс, - он пришел безоговорочно исполнить и заветы истории русской интеллигенции» $[12$, с. 204]. Большевистская идеология вся искалечена ее «родимыми пятнами»: «Фанатическое, религиозное преклонение перед материальной культурой и материальным прогрессом подготовило активно материалистический культ октябрьской революции, а систематически воспитываемое недружелюбие к началам нации и государственности <...> привело к безгосударственному космополитизму идеологии интернационала» [12, с. 204].

Устрялов пишет, что октябрь 1917 г. явился для русской интеллигенции «апофеозом и судом Немезиды»: образ легко расшифровываемый, если учесть, что эта античная богиня возмездия карала за нарушение общественных и нравственных порядков. У отказавшейся сотрудничать с большевиками интеллигенции было три сценария: «или мартиролог, или реестр каторги», или эмиграция. Фактически она вместе с дворянством выпадает из социальной стратификации и теряет прежнюю идентичность: «Произошла трагическая борьба, в которой восставшая против самой себя, против своей истории, армия русской интеллигенции была разбита наголову» [12, с. 210].

Гражданская война и интервенция («Вандея и Кобленц») у Устрялова поначалу являются точкой бифуркации («если победят они (большевики. $-A$. B.), значит они нужны России, значит, история пойдет через них») [12, c. 122]). Позднее, по аналогии с французской революцией, белому движению и интервенции были приданы функции внешнего «вызова», который заставил большевиков отстраивать эффективные государственные структуры (прежде всего армию) и подводил их к решению национальных задач: «Осуществляя себя, освободительная идея облекалась в латы и опоясывалась мечом. На первый план выдвигалась армия <..> И, как следствие, энтузиазм общечеловеческий постепенно уступал место в революционной борьбе энтузиазму национальному» [12, с. 139-140]). Но они же, как ни парадоксально, «заморозили» революционный пик: «Кризис ортодоксального коммунизма, вероятно, произошел бы еще раньше, если бы не было белых движений, искусственно расширявших социальную базу коммунистической власти» [12, с. 148].

Далее наступает «термидор». По счастью, Устрялов развернуто высказался по этой теме (прежде всего в статье «Путь термидора» 1921 г.). Если по вопросу о «якобинцах» в представлениях тогдашней публицистики существовал ясный консенсус, и даже сами большевики были не прочь согласиться с такой параллелью [11, с. 29], то «термидор» превратился в «псевдоморфозу» (терминпустышку), в которую каждый вкладывал свое содержание. Н.П. Милюков считал им Кронштадское восстание, один из знакомых Устрялова - переезд большевиков из Петрограда в Москву [12, с. 339], у Л.Д. Троцкого границы «советского термидора» вообще оказались достаточно размытыми. Устрялов понимает «термидор» не как переворот, а как процесс, когда революция начинает идти на спад и возникает ясность, что основными ее приоритетами являются национальные задачи. Он обозначает два сценария «термидора». Первый был реализован во Франции (переворот и казнь Робеспьера, олицетворявшего якобинскую диктатуру). Но существовал и второй: Устрялов приводит слова Наполеона о том, что если бы Робеспьер удержал за собой власть, он изменил бы свой образ действий $[12$, c. 88$]$. То есть это сценарий приспособления «лидеров движения к новой фазе» $[12$, c. 93]. Как предполагал Устрялов, русский «термидор» пойдет именно по этому сценарию, продлится гораздо дольше, чем француз- 
ский и будет проходить в старой «оболочке» («под знаком революционной, советской власти» [12, с. 118]).

Хронологически русский «термидор» начинается после подавления кронштадского восстания, отмены политики военного коммунизма и перехода к НЭПу. К 1927 г. он, по мнению Устрялова, еще не был завершен. Устрялов называет его «сумерками», а для характеристики использует известный гегелевский образ («сова Минервы вылетает в сумерках»). Образ понятен: рефлексия наступает именно на фазе спада, когда и начинают выявляться подлинные цели всего процесса. Однако, если обычно этот образ используют для того, чтобы обозначить осознание прошедшего, то Устрялов предполагает в «сумерках революции» увидеть контуры будущего. На этом этапе отчетливо начинает проявляться тот характерный признак революции, который он, пользуясь терминологией В. Вундта, обозначает как «гетерогения целей» (см.: [12, c. 174-176]). Основан он на том, что «цели/задачи» и «средства/методы» могут меняться местами: то, что изначально кажется побочным и второстепенным (то есть методом) для достижения некой цели, оказывается конечной целью (с точки зрения исторической перспективы), а то, что ранее провозглашалось как основная задача, оказывается лишь средством. Процесс, в результате которого начинают проявляться истинные цели революции, он обозначает как «национализация». Она характеризуется сближением и взаимовлиянием тех активных сил, которые совершили революцию, и остальной части общества («Ближе к массам! Глубже в быт!»), чего невозможно было представить на этапе подъема и пика. Например, очень интересно, что при вхождении в «плотные слои» народных масс начинают профанироваться некоторые элементы «сакрального пространства» революции: «Мне самому пришлось этим летом не раз слышать в России, как царский “мерзавчик" величают "пионером", а сороковку - "комсомольцем"» [12, с. 195]. И Устрялов не видит здесь ничего плохого: для него это, скорее, отрадный индикатор глубины происходящего процесса.

«Термидор» должен завершаться «брюмером». Устрялов в своей публицистике 1920-
1927 гг. не проясняет деталей этого этапа, говорит о нем крайне мало, скорее, просто бросает несколько «несвоевременных» мыслей. Более развернуто о сценариях русского «брюмера» (в плане политологического прогноза) он пишет в переписке 1929 года. Напомним, что во время французской революции «брюмер» был концом революции и одновременно законодательным закреплением ее реальных/ национальных итогов (знаменитый кодекс Наполеона). В политическом плане он протекал в форме автократии («бонапартизм»). В публицистике 1920-1927 гг. Устрялов лишь констатирует неизбежность русского «брюмеpa» (см.: [11, с. 30]) и указывает на то, что Наполеон вышел из якобинской среды, явно прочерчивая возможный сценарий развития русской революции в этой фазе [12, с. 89]. В письме к П.П. Сувчинскому 1927 г. он указывает на возможную бифуркацию процесса (грядущий «перебой» в революции - это или переворот по типу 9 термидора или «брюмерообразный скачок»), тогда Устрялов еще не был готов увидеть появление нового Наполеона [13, с. 31]. Но в письмах 1929 г. «фокус» устряловского анализа становится резче: он определяет основные параметры русского «брюмера», по сути инвариантные французскому, указывая, что «бонапартизм» - это «подлинная кодификация революции», «стабилизация новых социальных интересов, созданных революцией», «равноденствующая революции, ее осуществленная реальность», «реакция, спасающая и закрепляющая революцию» $[11$, c. 40]. Здесь же он четко высказывает мысль, что основная фигура русского «брюмера»Сталин $[11$, с. 41]. Успех его действий Устрялов связывает с «мамелюкизацией» правящего слоя. Аналогия понятна: успех может быть достигнут путем трансформации правящего слоя таким образом, что внутри себя он лишится прочных горизонтальных и вертикальных связей и будет зависеть только от основного носителя власти/диктатора. Устрялов считает, что к 1929 г. Сталин уже отчасти осуществил такую работу («Он окружил власть нерассуждающими, но повинующимися солдатами от политики» [11, с. 41]). И здесь же Устрялов предупреждает о той опасности, которая может поджидать Сталина, если ему не удастся превратить «мамелюкизацию» в ос- 
новной принцип существования правящего слоя: «В один прекрасный день его забрыкают собственные ослы, жаждущие спокойных стойл» [11, с. 42].

Результаты. На наш взгляд, Устрялов понимает революцию прежде всего, как инструмент для решения национальных задач. $\mathrm{C}$ феноменологической точки зрения революция представляет собой явление, обладающее самостоятельной логикой, подчиненное определеным законам и проходящее определенные этапы своего развития, не зависящие от воли и желаний ее акторов. Революцию Устрялов сравнивает с Пигмалионом (аллюзия к известной пьесе Б. Шоу), который в определенный момент вкладывает нужные мысли своим креатурам [12, с. 90]: то есть на каждом этапе своего развития логика революционного процесса создает для его движущих сил такой коридор возможностей и такое направление движения, которое неизбежно приводит к следующему этапу. Причины такого развития скрыты в самой революции и имманентно ей присущи (Устрялов выражал его через образ «стихии»): широта и разнообразие участвующих в революции сил (масс, партий, групп, фракций и т. д.) создает условия для отбора той из них, которая наиболее адекватно отражает параметры следующего этапа. В своем анализе Устрялов опирался на логику и этапы развития французской революции, по сути, считая их инвариантными. Различие наблюдается только во второстепенных признаках: сроки, альянсы групп, разница в сценариях протекания этапов и т. д. Общим для всех революций является основная их конфигурация (синусоида), где пиковое развитие приходится на середину процесса, а также «гетерогения целей», когда «чистые идеи» из цели превращаются в средство.

Благодаря подобной оценке революции Устряловым была намечена такая версия истории России XX в., которая самым оптимальным образом объясняет историческую преемственность двух эпох ее развития на современном историческом этапе (эпоха Российской империи и эпоха России советской/СССР). Если взглянуть на всю историю России, то (не учитывая новейший период) в ней можно выделить три исторических «разрыва»: между Киевской Русью и Русью Московской, между
Московской Русью и Российской империей, между Российской империей и СССР. Но если по поводу двух первых «разрывов» давно уже найден консенсус, который объясняет историческую преемственность этих этапов (по сути, он перекочевал в советские учебники из дореволюционных и остается в целом таким и сейчас), то в случае с последним «разрывом» консенсуса не возникло, существуют лишь разные и подчас взаимоисключающие версии.

Попробуем проанализировать главные из них. Прежняя советская версия находилась в рамках «философии формаций» и объясняла линейное поступательное движение через их смену (от низшей к высшей): но сложно в таком случае объяснить, каким образом Россия после 1991 г. перекочевала из более высокой формации (социализм) в более низкую (капитализм). Либеральные версии трактуют советский период как «черное пятно», отступление от правильного развития, а его структурообразующим элементом выступает период массовых репрессий 1930-х годов. Однако, как показывает действительность, эти версии травмируют историческую память большинства населения современной России, поскольку советский период вызывает там не только негативные, но и позитивные коннотации $[5 ; 8]$. Наконец, современная версия русской истории (по материалам открытых источников можно сделать вывод, что ее разработку курируют два восстановленных исторических общества, РИО и РВИО [4]) предлагает довольно эклектичную картину, где всячески превозносится период Российской империи, а в отношении советского времени применяется «фигура умолчания», в лучшем случае из него механически вынимаются отдельные события (прежде всего победа в Великой Отечественной войне [4]). Квинтессенцией подобного подхода можно считать отказ современного российского руководства отмечать столетие русской революции [7]. Однако, судя по откликам в Интернете, такая позиция также не находит понимания.

«Версия Устрялова» (для краткости назовем ее так), находящаяся в рамках цивилизационного подхода, позволяет трактовать историю СССР как такую форму существования России на определенном временном этапе, которая оказалась способна эффектив- 
но отвечать на внутренние и внешние «вызовы» (наиболее важными из них были Вторая мировая война и сложная послевоенная обстановка), а также смогла обеспечить суверенное и поступательное развитие русского государства. Эта версия, как нам представляется, имеет две «болевые точки». Если сохранить ее логической и непротиворечивой, то развитие России в начале XX в. следует признать неэффективным и неадекватно отвечающим на исторические «вызовы», а события февраля 1917 г. следует считать не упущенным историческим шансом, а временем распада и энтропии, неизбежно выводящими на историческую авансцену большевиков. С первым положением не согласятся «новые белые», со вторым - либералы. Но, с нашей точки зрения, для большинства населения современной России (см. данные соцопросов) эта версия может непротиворечиво объяснить историческое развитие страны, не травмируя его историческую память.

\section{СПИСОК ЛИТЕРАТУРЫ}

1. Агурский, М. С. Идеология национал-большевизма / М. С. Агурский. - М. : Алгоритм, 2003.$320 \mathrm{c}$.

2. Булычева, М. В. Политическая концепция государства в теоретическом наследии Н. В. Устрялова : автореф. дис. ... канд. полит. наук / Булычева Марина Владимировна. - Саратов, 2007. - 19 c.

3. Довбыш, А. В. Трансформация воззрений Н.В. Устрялова на советское государство / А. В. Довбыш // Вестник Нижегородского университета им. Н.И. Лобачевского. - 2016. - № 3. - С. 131-137.

4. Кацевич, М. Путин создает сеть элитных обществ для людей во власти / М. Кацевич. - Электрон. текстовые дан. - Режим доступа: https://tip.by/ putin-sozdaet-set-jelitnyh-obshhestv-dlja-ljudej-vovlasti (дата обращения: 15.08.2018). - Загл. с экрана.

5. «Левада-центр»: $68 \%$ россиян хотели бы возвращения к социализму и СССР // Ведомости. 2016. - 19 апр. - Электрон. текстовые дан. - Режим доступа: https://www.vedomosti.ru/politics/news/ 2016/04/19/638242-68-rossiyan-sotsializmu (дата обращения: 29.08.2018). - Загл. с экрана.

6. Лысенко, Е. А. История идеологии национал-большевизма Н.В. Устрялова (1900-е гг. 1925 г.) : автореф. дис. ... канд. ист. наук / Лысенко Елена Анатольевна. - СПб., 2007.- 21 c.

7. Песков не увидел необходимости в праздновании 100-летия революции. - Электрон. тексто- вые дан. - Режим доступа: https://www.gazeta.ru/ politics/news/2017/10/25/n_10735148.shtml (дата обращения: 17.08.2018). - Загл. с экрана.

8. Почти две трети россиян хотели бы сохранить СССР - ВЦИОМ // Ведомости. - 2016. - 16 марта. Электрон. текстовые дан. - Режим доступа: https: //www.vedomosti.ru/politics/news/2016/03/16/633782pochti (дата обращения: 29.08.2018). - Загл. с экрана.

9. Романовский, В. К. Николай Васильевич Устрялов. Деятельность и эволюция идейно-политических воззрений (1890-1937 гг.) : автореф. дис. ... д-ра ист. наук / Романовский Вячеслав Константинович. - Н. Новгород, 2007. - 51 с.

10. Романовский, В. К. Великая русская революция в оценках политического мыслителя Н.В. Устрялова / В. К. Романовский // Преподаватель XXI в. 2017. -№ 2. - С. 264-276.

11. Устрялов, Н. В. Национал-большевизм / Н. В. Устрялов ; сост., прим., коммент. С. М. Сергеева. - М. : Эксмо-Алгоритм, 2003. - 656 с.

12. Устрялов, Н. В. Национал-большевизм. Избранные статьи 1920-1927 гг. / Н. В. Устрялов ; ред.-сост. М. Колеров. - М. : Издание книжного магазина «Циолковский», 2017. - 400 с.

13. Устрялов, Н. В. Письма к П.П. Сувчинскому. 1926-1930 / Н. В. Устрялов ; сост., подгот. текста, вступ. ст. и примеч. К. Б. Ермишиной. - М. : Дом русского зарубежья им. А. Солженицына, 2010. $-80 \mathrm{c}$.

14. Утяшев, М. М. Большевизм как национальная власть: взгляд на события 20-30-х гг. XX в. в СССР с точки зрения Н.В. Устрялова / М. М. Утяшев, И. И. Муллахметов // Вестник Башкирского университета. - 2012. - Т. 17, № 3. - С. 1385-1388.

\section{REFERENCES}

1. Agurskiy M.C. Ideologiya natsionalbolshevizma [Ideology of National Bolshevism]. Moscow, Algoritm Publ., 2003.320 p.

2. Bulycheva M.V. Politicheskaya kontseptsiya gosudarstva v teoreticheskom nasledii N. V. Ustryalova: avtoref. dis. ... kand. polit. nauk [The Political Concept of the State in the Theoretical Heritage of N.V. Ustryalov. Cand. polit. sci. abs. diss.]. Saratov, 2007. 19 p.

3. Dovbysh A.V. Transformatsiya vozzreniy N.V. Ustryalova na sovetskoe gosudarstvo [Transformation of N.V. Ustryalovs Ideas on the Soviet State]. Vestnik Nizhegorodskogo universiteta im. N.I. Lobachevskogo [Vestnik of Lobachevsky University of Nizhni Novgorod], 2016, no. 3, pp. 131-137.

4. Katsevich M. Putin sozdaet set elitnykh obshchestv dlya lyudey vo vlasti [Putin Creates Elite Societies Network for People in Power]. URL: https:// 
tip.by/putin-sozdaet-set-jelitnyh-obshhestv-dljaljudej-vo-vlasti (accessed 15 August 2018).

5. «Levada-tsentr»: $68 \%$ rossiyan khoteli by vozvrashcheniya k sotsializmu i SSSR [Levada Center: $68 \%$ of Russians Would Like to Return to Socialism and to the USSR]. Vedomosti, 2016, April 19. URL: https:/www.vedomosti.ru/politics/news/2016/04/19/ 638242-68-rossiyan-sotsializmu (accessed 29 August 2018).

6. Lysenko E.A. Istoriya ideologii natsionalbolshevizma N.V. Ustryalova (1900-e gg. - 1925 g.): avtoref. dis. ... kand. ist. nauk [The History of the Ideology of National Bolshevism by N.V. Ustryalov (1900s - 1925s). Cand. hist. sci. abs. diss.]. Saint Petersburg, 2007. $21 \mathrm{p}$.

7. Peskov ne uvidel neobkhodimosti v prazdnovanii 100-letiya revolyutsii [Peskov Did Not See the Need to Celebrate the $100^{\text {th }}$ Anniversary of the Revolution]. URL: https://www.gazeta.ru/politics/ news/2017/10/25/n_10735148.shtml (accessed 17 August 2018).

8. Pochti dve treti rossiyan khoteli by sokhranit SSSR - VTsIOM [Almost Two Thirds of Russians Would Like to Save the USSR - Russian Public Opinion Research Center(VTsIOM)]. Vedomosti, 2016, March 16. URL: https://www.vedomosti.ru/politics/news/2016/ 03/16/633782-pochti (accessed 29 August 2018).

9. Romanovskiy V.K. Nikolay Vasilyevich Ustryalov. Deyatelnost i evolyutsiya ideyno- politicheskikh vozzreniy (1890-1937 gg.): avtoref. dis. ... d-ra ist. nauk [Nikolay Vasilyevich Ustryalov. Activity and Evolution of Ideological and Political Views (1890-1937). Cand. hist. sci. abs. diss.]. Nizhny Novgorod, 2007. $51 \mathrm{p}$.

10. Romanovskiy V.K. Velikaya russkaya revolyutsiya $\mathrm{v}$ otsenkakh politicheskogo myslitelya N.V. Ustryalova [The Great Russian Revolution in the Assessments of Political Thinker N.V. Ustryalov]. Prepodavatel XXI v., 2017, no. 2, pp. 264-276.

11. Ustrialov N.V. Natsional-bolshevizm [National Bolshevizm]. Moscow, Eksmo-Algoritm Publ., 2003. 656 p.

12. Ustrialov N.V. Natsional-bolshevizm. Izbrannye statyi 1920-1927 gg. [National Bolshevizm. Selected Articles of 1920-1927]. Moscow, Izdanie knizhnogo magazina «Tsiolkovskiy», 2017.400 p.

13. Ustrialov N.V. Pisma k P.P. Suvchinskomu. 1926-1930 [Letters to P. Suvchinsky, 1926-1930]. Moscow, Dom russkogo zarubezhya im. A. Solzhenitsyna, 2010.80p.

14. Utyashev M.M. Bolshevizm kak natsionalnaya vlast: vzglyad na sobytiya 20-30-kh gg. XX v. v SSSR s tochki zreniya N.V. Ustryalova [Bolshevism as a National Power: A Look at the Events of the 20s - 30s of the $20^{\text {th }}$ Century in the USSR from the Point of View of N.V. Ustrialov]. Vestnik Bashkirskogo universiteta [Bulletin of Bashkir University], 2012, vol. 17, no. 3, pp. 1385-1388.

\section{Information About the Author}

Anton A. Voytenko, Doctor of Sciences (History), Leading Researcher, Centre for Egyptological Studies of the Russian Academy of Sciences, Prosp. Leninskiy, 29, Bld. 8, 119071 Moscow, Russian Federation, cesras@cesras.ru, https://orcid.org/0000-0002-3895-9909

\section{Информация об авторе}

Антон Анатольевич Войтенко, доктор исторических наук, ведущий научный сотрудник, Центр египтологических исследований РАН, просп. Ленинский, 29, стр. 8, 119071 г. Москва, Российская Федерация, cesras@cesras.ru, https://orcid.org/0000-0002-3895-9909 